\title{
PENGEMBANGAN MODUL ANALISIS BUTIR SOAL DENGAN MENGGUNAKAN ITEM AND TEST ANALYSIS
}

\author{
Anggit Prabowo ${ }^{a}$, Sunaryo ${ }^{\mathrm{b}}$, Uki Rahmawati ${ }^{\mathrm{c}}$ \\ ${ }^{a}$ Program Studi Pendidikan Matematika FKIP UAD \\ Jl. Prof. Dr. Soepomo, SH. Janturan Yogyakarta, anggit.prabowo@pmat.uad.ac.id \\ ${ }^{\mathrm{b}}$ Program Studi Pendidikan Matematika FKIP UAD \\ Jl. Prof. Dr. Soepomo, SH. Janturan Yogyakarta, sunaryo@uad.ac.id \\ ${ }^{c}$ SEAMEO QITEP in Mathematics \\ Jl. Kaliurang, Condongcatur, Depok, Sleman, Yogyakarta, uki.rahmawati@gmail.com
}

\begin{abstract}
ABSTRAK
Tujuan penelitian ini adalah untuk mengembangkan modul analisis butir soal dengan menggunakan software Item and Test Analysis (ITEMAN). Penelitian ini merupakan penelitian pengembangan dengan model Four D yang terdiri atas tahap define, design, develop, dan disseminate. Modul yang dikembangkan telah dianalisis oleh 2 ahli materi dan 2 ahli media. Setelah dinyatakan valid oleh para ahli, modul diujicobakan kepada 19 guru dan 45 mahasiswa calon guru. Modul yang telah diperbaiki berdasar hasil uji coba, didiseminasikan kepada 31 guru dan 45 mahasiswa calon guru. Penelitian telah berhasil mengembangkan produk berupa modul analisis butir soal dengan menggunakan ITEMAN yang terkategori valid, efektif, dan praktis.
\end{abstract}

Kata Kunci : pengembangan, modul, analisis butir soal, item and test analysis.

\begin{abstract}
The purpose of this research is to develop the item analysis module using Item and Test Analysis (ITEMAN) software. This research is a development research with Four D model which consists of define, design, develop, and disseminate. The developed module has been analyzed by 2 material experts and 2 media experts. After being declared valid by the experts, the module was tested to 19 teachers and 45 prospective teachers. Modules that have been revised based on trial results, were disseminated to 31 teachers and 45 prospective teachers. The research has succeeded in developing a valid, effective, and practical module of item test analysis using ITEMAN.
\end{abstract}

Key words: developing, module, item analysis, item and test analysis. 


\section{Pendahuluan}

Keberhasilan suatu pembelajaran dapat diketahui melalui kegiatan penilaian. Dalam sistem pendidikan di Indonesia, penilaian keberhasilan belajar peserta didik dilakukan oleh beberapa pihak. Menurut Permendiknas Nomor 20 Tahun 2007, penilaian hasil belajar pada jenjang pendidikan dasar dan menengah dilaksanakan oleh pendidik, satuan pendidikan, dan pemerintah.

Penilaian hasil belajar oleh ketiga pihak di atas dilaksanakan sesuai dengan kapasitas masing-masing. Pendidik melakukan penilaian melalui ulangan harian. Satuan pendidikan melakukan penilaian dalam bentuk ujian tengah semester, ujian akhir semester, dan ujian kenaikan kelas. Pemerintah melakukan penilaian hasil belajar peserta didik secara nasional dalam bentuk Ujian Nasional (UN).

Penilaian tidak dapat dilepaskan dari kegiatan pengukuran. Kegiatan pengukuran dapat terlaksana jika tersedia instrumen pengukuran. Kualitas instrumen sangat menentukan kualitas hasil pengukuran. Instrumen yang baik akan menghasilkan penilaian yang baik. Sebaliknya, instrumen yang tidak baik akan menghasilkan hasil penilaian yang menyesatkan.

Pengembangan ... (Anggit Prabowo)
Instrumen yang baik adalah instrumen yang disusun sesuai dengan tujuan pengukuran. Instrumen harus dikembangkan sesuai dengan prosedur pengembangan instrumen yang baku. Instrumen yang baik adalah instrumen yang telah dianalisis baik secara kualitatif maupun kuantitatif. Analisis kualitatif merupakan analisis yang dilakukan sebelum soal tersebut diujicobakan atau digunakan. Analisis ini mencakup analisis validitas yang meliputi materi, konstruksi, dan bahasa. Analisis materi dilakukan untuk menjamin bahwa materi yang diujikan sesuai dengan materi yang telah diajarkan dan sesuai dengan kisikisi. Analisis kontruksi dilakukan untuk memastikan bahwa butir-butir di dalam instrumen tersebut telah terkonstruksi dengan baik. Analisis yang dilakukan meliputi keseluruhan format dan keajegan editorial dari butir yang satu ke butir yang lainnya. Analisis dari segi bahasa dilakukan untuk menjamin bahwa setiap butir soal ditulis dengan menggunakan kaidah bahasa Indonesia yang baik dan benar.

Analisis kuantitatif adalah analisis yang dilakukan setelah instrumen diujicobakan atau digunakan. Analisis ini didasarkan pada respons responden uji coba atau peserta tes. Analisis kuantitatif meliputi analisis tentang tingkat 
kesukaran (item difficulty), daya pembeda (discrimination), keberfungsian pengecoh (untuk soal pilihan ganda), dan reliabilitas. Tingkat kesukaran butir soal merupakan proporsi peserta tes menjawab benar butir tersebut. Daya pembeda suatu butir soal adalah kemampuan suatu butir tes untuk membedakan kelompok dalam spek yang diukur sesuai dengan perbedaan yang ada dalam kelompok itu.

Instrumen penilaian terdiri atas instrumen tes dan non tes. Tes adalah suatu prosedur standar untuk mendapatkan suatu sampel kelakuan dari domain yang spesifik (Crocker dan Algina, 2008; Kereh, Liliasari, Tjiang, dan Sabandar, 2015:38). Menurut Ary, Jacobs, dan Razavieh (2010), tes adalah sekumpulan rangsangan yang diberikan pada seseorang yang bertujuan untuk memeroleh tanggapan yang kemudian diskor.

Salah satu langkah dalam prosedur pengembangan instrumen tes adalah menganalisis butir soal secara kuantitatif. Analisis ini dilakukan berdasar data yang diperoleh secara empirik yang berupa respons jawaban dari peserta tes. Langkah ini dilaksanakan setelah pengembang instrumen menentukan spesifikasi instrumen tes, menulis butir-butir pernyataan, menganalisis secara kuantitatif, mengkonstruksi

tes,

dan

mengujicobakannya.

Hasil wawancara peneliti dengan guru-guru dari berbagai daerah menunjukkan bahwa sejauh ini pendidik belum maksimal dalam melakukan analisis butir soal (Prabowo dan Astuti, 2017:7). Hal ini dikarenakan salah satunya adalah kegiatan analisis butir soal merupakan kegiatan yang rumit dan menyita banyak waktu. Permasalahan ini dikarenakan bahwa dalam analisis butir soal selalu melibatkan operasi-operasi matematika yang tidak semua pendidik memahaminya. Padahal, Instructional Assessment Resources menyatakan bahwa analisis butir soal itu penting karena mampu menyediakan informasi yang berguna untuk meningkatkan kualitas dan akurasi tes (IAR, 2011).

Saat ini banyak software yang dapat digunakan sebagai alat bantu untuk melakukan analisis butir soal, salah satunya adalah Item and Test Analysis (ITEMAN). ITEMAN adalah program yang dikembangkan oleh Assessment Systems Corporation (Pisowacka: 2015:538). Hasil analisis yang ditampilkan dalam program ini merupakan analisis menggunakan classical test theory (CTT). Hasil dari analisi yang ditampilkan meliputi tingkat kesukaran, daya beda, dan statistik penyebaran jawaban, realibilitas tes, 
kesalahan pengukuran, dan distribusi skor (Rosana \& Setyawarno, 2016: 19). Mengingat kebermanfaat ITEMAN sebagai alat untuk menganalisis butir soal, maka perlu dikembangkan modul yang valid, efektif, dan praktis tentang cara melakukan analisis butir dengan menggunakan software tersebut.

\section{Metode Penelitian}

Jenis penelitian ini adalah penelitian pengembangan dengan model Four-D yang terdiri atas tahap define, design, develop, dan disseminate (Thiagarajan, 1974:5) seperti pada gambar 1.

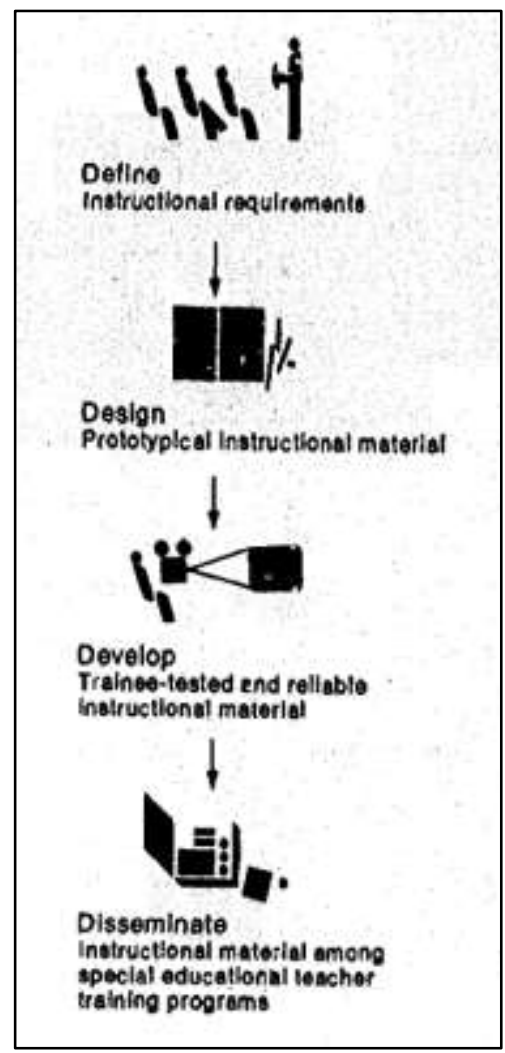

Gambar 1. Desain Penelitian

Pengembangan

Pengembangan ... (Anggit Prabowo)
Prosedur pengembangan produk pada penelitian ini diawali dengan mendefinisikan produk yang akan dikembangkan. Setelah didefinisikan, produk kemudian didesain dan dikembangkan. Produk yang dikembangkan kemudian dianalisis kevalidannya oleh ahli materi dan ahli media. Setelah dinyatakan valid, produk diujicobakan kepada 12 guru dan 45 mahasiswa calon guru. Selanjutnya, produk didiseminasikan kepada 31 guru dan 45 mahasiswa calon guru.

Penelitian ini dilaksanakan di program studi pendidikan matematika FKIP UAD. Waktu pelaksanaan penelitian ini adalah bulan April sampai dengan Oktober 2017. Instrumen penelitian ini adalah kuesioner untuk mengukur kevalidan, keefektifan, dan kepraktisan produk yang telah dikembangkan. Jenis data dalam penelitian ini adalah data kualitatif dan kuantitatif. Data kualitatif yang diperoleh pada penelitian berupa saran atau masukan dari validator dan subjek ujicoba. Data kuantitatif diperoleh dari skor tanggapan validator terhadap produk, dan skor respons responden uji coba.

Data yang didapatkan dianalisis secara deskriptif kualitatif. Analisis AdMathEdu | Vol.7 No.2 | Desember 2017 
kevalidan produk yang dikembangkan mengacu pada tabel 1 .
Tabel 2. Kriteria Penilaian Keefektifan

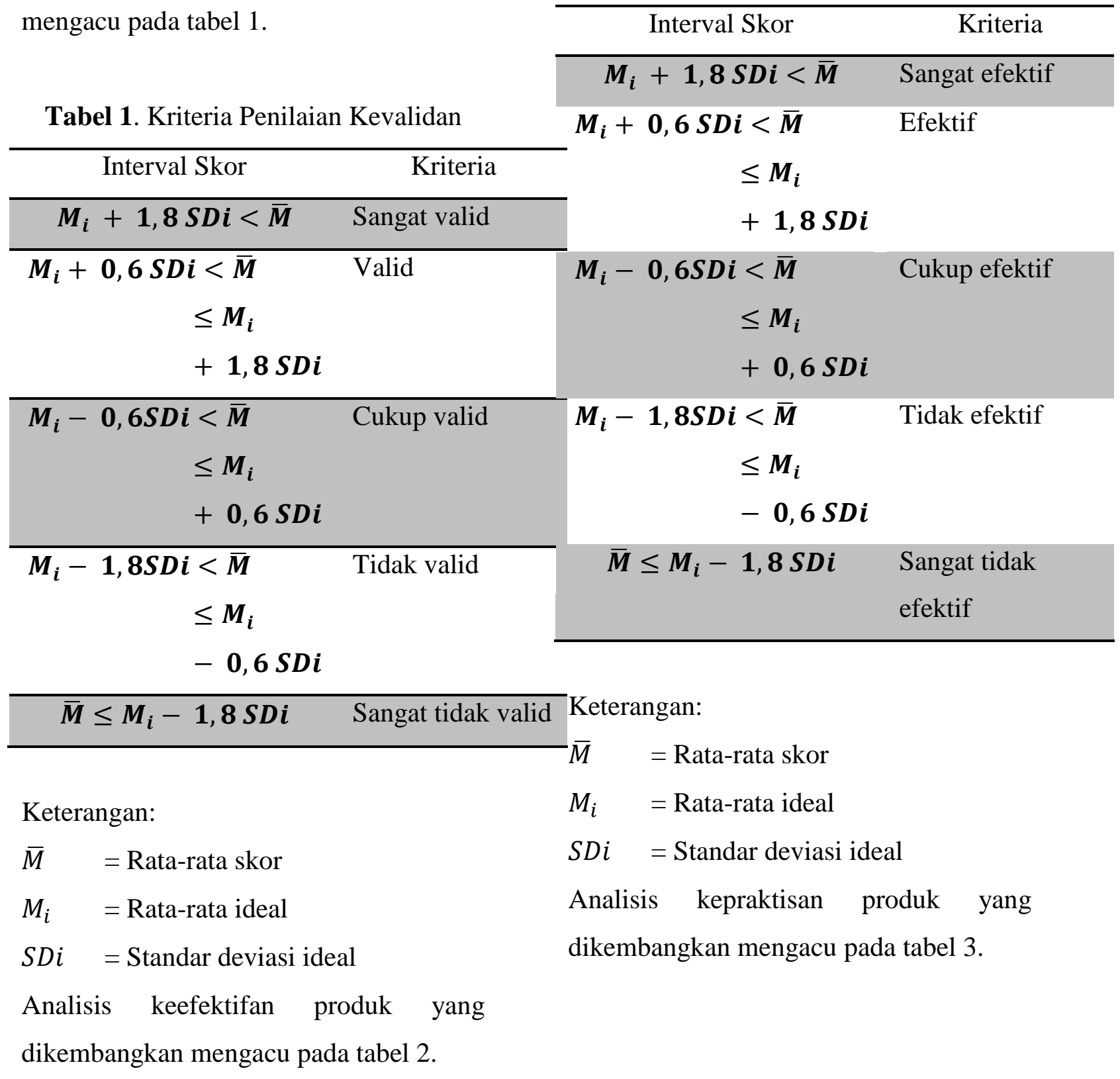

Tabel 1. Kriteria Penilaian Kevalidan 
Tabel 3. Kriteria Penilaian Kepraktisan

\begin{tabular}{|c|c|}
\hline Interval Skor & Kriteria \\
\hline$M_{i}+1,8 S D i<\bar{M}$ & Sangat praktis \\
\hline $\begin{aligned} M_{i}+0,6 S D i & <\bar{M} \\
& \leq M_{i} \\
& +1,8 S D i\end{aligned}$ & Praktis \\
\hline $\begin{aligned} M_{i}-0,6 S D i & <\bar{M} \\
& \leq M_{i} \\
& +0,6 S D i\end{aligned}$ & Cukup praktis \\
\hline $\begin{aligned} M_{i}-1,8 S D i & <\bar{M} \\
& \leq M_{i} \\
& -0,6 S D i\end{aligned}$ & Tidak praktis \\
\hline $\bar{M} \leq M_{i}-1,8 S D i$ & $\begin{array}{l}\text { Sangat tidak } \\
\text { praktis }\end{array}$ \\
\hline
\end{tabular}

Keterangan:

$\bar{M} \quad=$ Rata-rata skor

$M_{i} \quad$ = Rata-rata ideal

$S D i=$ Standar deviasi ideal

\section{Hasil dan Pembahasan}

Pengembangan modul analisis butir soal menggunakan ITEMAN dilaksanakan melalui tahap define, design, develop, dan disseminate.

\section{Define}

Produk yang dikembangkan dalam penelitian ini berupa Modul Analisis Butir Soal dengan Menggunakan Item and Test Analysis (ITEMAN). Tampilan awal ITEMAN tersaji pada gambar 2 .

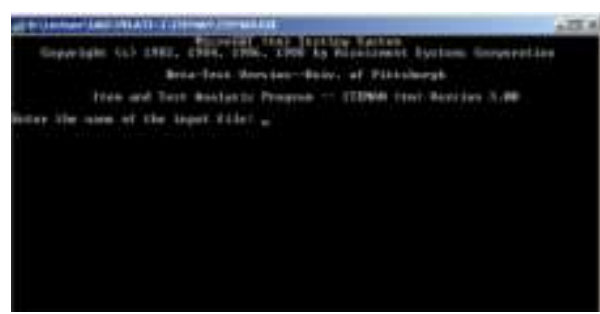

Gambar 2. Tampilan Awal ITEMAN

Modul yang dikembangkan dapat digunakan oleh pendidik maupun calon pendidik dalam melakukan analisis butir soal dengan menggunakan komputer. Tester tidak perlu lagi berhadapan dengan prosedur-prosedur menganalisis butir soal yang penuh dengan formula-formula dan melibatkan perhitungan yang cukup rumit. Dengan menggunakan ITEMAN, tester hanya perlu menginputkan data yang akan dianalisis kemudian dengan proses yang sangat singkat akan keluar hasil analisisnya. Untuk mempermudah penggunaan ITEMAN untuk menganalisis butir soal maka perlu dikembangkan modul analisis butir soal dengan menggunakan ITEMAN.

\section{Design}

Spesifikasi produk yang telah didefinisikan selanjutnya didesain sesuai dengan tujuan pengembangannya. Modul yang akan dikembangkan dirancang dengan konsep seperti tersaji pada tabel 4. 
Tabel 4. Desain Produk

\begin{tabular}{|c|c|}
\hline Kor & Ket \\
\hline $\begin{array}{c}\text { Halaman } \\
\text { depan }\end{array}$ & $\begin{array}{l}\text { Memuat judul modul, } \\
\text { nama penyusun, dan }\end{array}$ \\
\hline $\begin{array}{c}\text { Kata } \\
\text { pengantar }\end{array}$ & $\begin{array}{l}\text { Berisi informasi terkait } \\
\text { modul yang } \\
\text { dikembangkan dan ucapar } \\
\text { terima kasih }\end{array}$ \\
\hline Daftar isi & Berisi daftar isi modul \\
\hline $\begin{array}{c}\text { BAB I } \\
\text { Analisis } \\
\text { Butir Soal }\end{array}$ & $\begin{array}{l}\text { Berisi tentang konsep } \\
\text { dan manfaat analisis } \\
\text { butir soal }\end{array}$ \\
\hline $\begin{array}{c}\text { BAB II } \\
\text { Analisis } \\
\text { Butir secara } \\
\text { Kualitatif }\end{array}$ & $\begin{array}{l}\text { Berisi materi tentang } \\
\text { materi cara menganalisis } \\
\text { butir instrumen tes } \\
\text { objektif dan non objektif } \\
\text { secara kualitatif }\end{array}$ \\
\hline $\begin{array}{c}\text { BAB III } \\
\text { Analisis } \\
\text { Butir secara } \\
\text { Kuantitatif }\end{array}$ & $\begin{array}{l}\text { Berisi materi tentang } \\
\text { materi cara menganalisis } \\
\text { butir instrumen tes } \\
\text { objektif dan non objektif } \\
\text { secara kuantitatif }\end{array}$ \\
\hline $\begin{array}{c}\text { BAB IV } \\
\text { Analisis } \\
\text { Butir Soal } \\
\text { dengan } \\
\text { ITEMAN }\end{array}$ & $\begin{array}{l}\text { Berisi materi tentang } \\
\text { praktik analisis butir } \\
\text { soal dengan } \\
\text { menggunakan ITEMAN }\end{array}$ \\
\hline $\begin{array}{c}\text { Daftar } \\
\text { Pustaka }\end{array}$ & $\begin{array}{l}\text { Berisi referensi-referensi } \\
\text { yang digunakan sebagai } \\
\text { rujukan }\end{array}$ \\
\hline $\begin{array}{l}\text { Halaman } \\
\text { belakang }\end{array}$ & Berisi informasi penerbit \\
\hline
\end{tabular}

Modul sebagai produk dari penelitian ini didesain terdiri atas halaman depan sampai dengan halaman belakang yang didalamnya berisi 4 bab. Halaman depan berisi judul modul, nama penyusun, dan ilustrasi yang menggambarkan isi modul. Setelah halaman depan adalah halaman kata pengantar yang diiukuti dengan daftar isi modul. Bab I berisi materi tentang konsep analisis butir soal dan manfaat analisis butir soal. Bab II berisi materi tentang teknik dan prosedur analisis butir soal secara kualitatif. Butir soal yang dianalisis berupa butir soal tes pilihan ganda dan esai. Bab III berisi materi tentang analisis butir secara kuantitatif yang meliputi tingkat kesukaran, daya beda, keberfungsian pengecoh, dan reiabilitas. Bab IV berisi materi tentang analisis butir dengan menggunakan ITEMAN. Pada bab ini dibahas tentang karakteristik program ITEMAN dan panduan cara mengoperasikannya yang dilengkapi dengan contoh analisis berserta hasil analisisnya. Hasil analisis djelaskan secara rinci pada bab ini sehingga memudahkan pengguna untuk memahaminya.

\section{Develop}

Produk yang didesain kemudian dikembangkan dengan menggunakan alat bantu berupa seperangkat perconal computer yang dilengkapi dengan 
software microsoft office 2010 dan CorelDRAW X7. Pengembangan produk dilakukan dengan mengembangkan desain produk yang telah ditetapkan pada langkah kedua. Gambar 3 sampai dengan gambar 11 adalah produk yang telah dikembangkan.

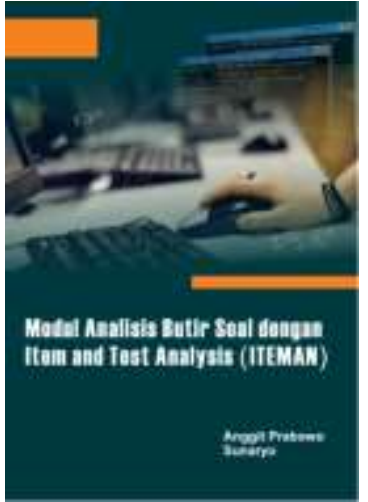

Gambar 3.

Halaman Depan

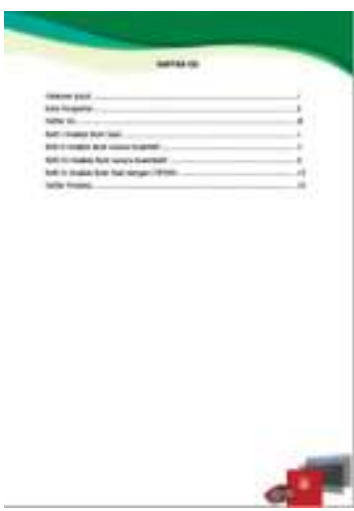

Gambar 5. Daftar isi

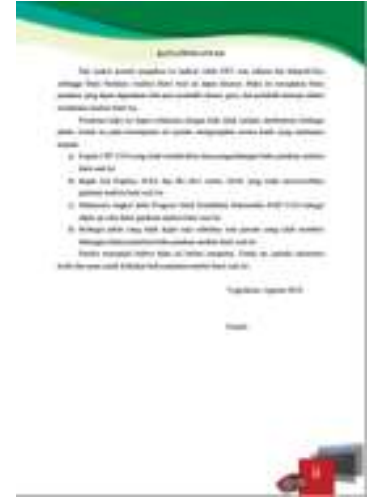

Gambar 4. Kata

Pengantar

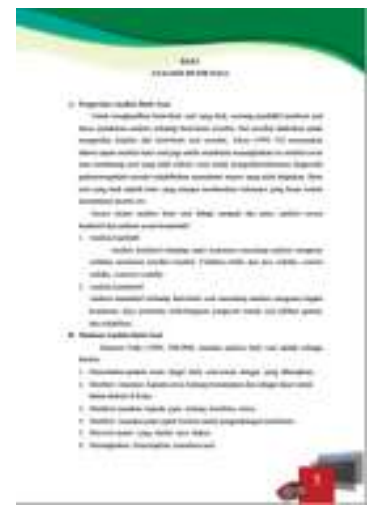

Gambar 6. BAB I
Pengembangan ... (Anggit Prabowo)

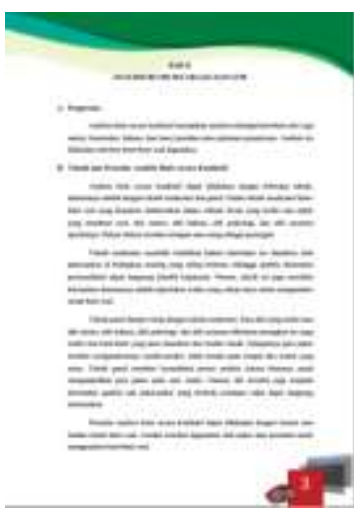

Gambar 7. BAB II

Gambar 8. BAB

III

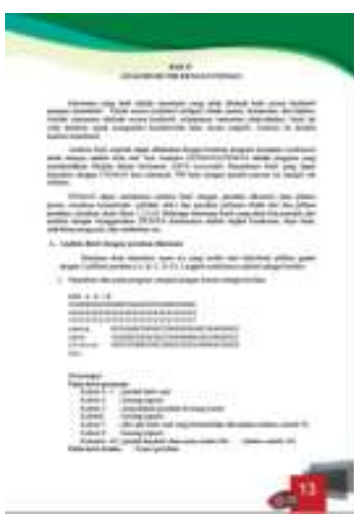

Gambar 9. BAB IV

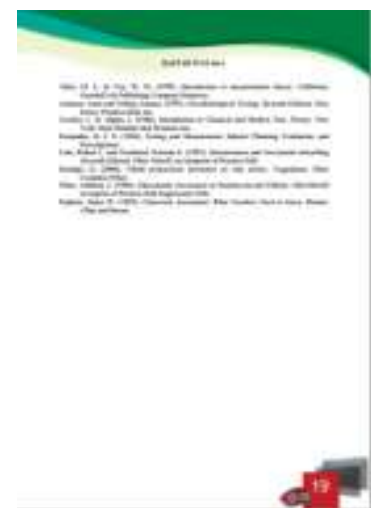

Gambar 10.

Daftar Pustaka

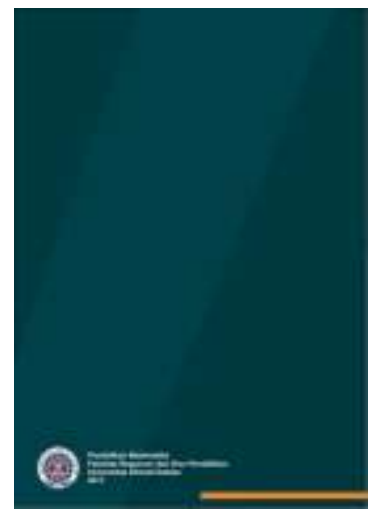

Gambar 11. Halaman Sampul Belakang

Produk yang telah dikembangkan selanjutnya dianalisis oleh ahli materi dan ahli media. Hasil analisis ahli materi didapatkan skor sebesar 3,90 dari skala 5. Dengan demikian secara materi produk AdMathEdu | Vol.7 No.2 | Desember 2017 
yang dikembangkan terkategori valid. Hasil analisis ahli media didapatkan skor sebesar 3,66 dari skala 5. Dengan demikian apabila ditinjau dari kualitas fisik produk yang dikembangkan terkategori valid. Berdasar analisis kedua ahli tersebut maka modul yang dikembangkan dinyatakan valid.

Produk yang dikembangkan selanjutnya diujicobakan kepada 19 guruguru matematika (gambar 12) dan 45 mahasiswa calon guru.

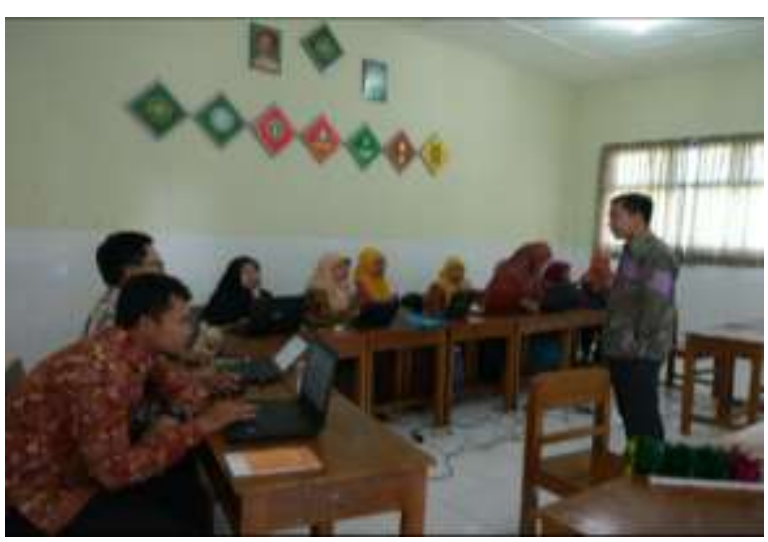

Gambar 12. Uji coba produk

Pada kegiatan ujicoba didapatkan respons dari peserta tentang modul yang dikembangkan. Respons tersebut tersaji pada tabel 5 .
Tabel 5. Pendapat guru terhadap Produk yang Dikembangkan

\begin{tabular}{clc}
\hline No & \multicolumn{1}{c}{ Pernyataan } & Persentase \\
\hline $\mathbf{1}$ & Menambah & $92 \%$ \\
& $\begin{array}{l}\text { pengetahuan tentang } \\
\text { ciri tes yang baik }\end{array}$ \\
$\mathbf{2}$ & Menambah \\
& pengetahuan dalam \\
& mengembangkan \\
& soal \\
$\mathbf{3}$ & Menambah \\
& pengetahuan dalam \\
& menganalisis butir \\
& soal \\
\hline
\end{tabular}

Berdasar tabel 4 dapat diketahui bahwa modul yang dikembangkan mampu menambah kemampuan guru dalam mengidentifikasi tes yang baik, mengembangkan soal, dan menganalisis butir soal. Skor keefektifan modul adalah sebesar 4,26 dari skala 5. Dengan demikian, produk yang dikembangkan terkategori efektif untuk membantu subjek uji coba untuk melakukan analisis butir soal.

$$
\text { Kepraktisan modul yang }
$$
dikembangkan untuk menganalisis butir soal dapat diidentifikasi dari respons subjek ujicoba terhadap produk yang dikembangkan. Hasil analisis kepraktisan diperoleh skor 4,18 dari skala 5. Dengan demikian produk yang dikembangkan terkategori praktis. 


\section{Disseminate}

Produk yang dikembangkan sudah didesiminasikan kepada 31 guru dan 45 mahasiswa calon guru. Hasil diseminasi menunjukkan bahwa guru sangat terbantu dengan adanya modul analisis butir dengan ITEMAN. Analisis butir dengan menggunakan ITEMAN menjadikan proses analisis menjadi lebih mudah.

Menganalisis butir hanya merupakan salah satu dari beberapa prosedur pengembangan instrumen penilaian baik tes maupun nontes. Pada dasarnya untuk mendapatkan instrumen yang baku memerlukan proses yang panjang (Jamilah dan Purnaman, 2009:122). Dengan demikian untuk mendapatkan instrumen yang baku, perlu dipastikan bahwa prosedur-produr yang lain mulai dari menentukan spesifikasi instrumen hingga melakukan analisis hasil pengukuran terlaksana dengan baik.

Dua teori utama dalam bidang pengukuran dan penilaian adalah teori tes klasik dan teori tes modern. Istilah lain dari teori tes klasik adalah Classical True-Score Theory (Suwarto, 2011:69). Teori ini dimakan teori tes klasik dikarenakan teori sudah dikembangkan sejak dahulu dan sampai sekarang masih digunakan. Salah satu teori pengukuran yang tertua di dunia pengukuran (Lababa, 2008:30).

Pengembangan ... (Anggit Prabowo)
Teori pengukuran dengan teori tes modern disebut juga dengan Latent-Trait Theory. Hal ini dikarenakan teori mengasumsikan bahwa kemampuan peserta tes dalam mengerjakan soal dapat diprediksi dari kemampuan peserta tes tersebut. Kemampuan tersebut besifat laten. Teori ini disebut juga dengan Item Response Theory atau teori respons butir. Disebut demikian karena pada teori ini karena respons yang diberikan oleh peserta tes akan menunjukkan kemampuan kognitif peserta tes tersebut.

Analisis butir soal dapat dilakukan dengan bantuan program komputer. ITEMAN merupakan program komputer yang digunakan untuk menganalisis butir soal secara klasik (Otaya, 2014:231). Untuk menjalankan program ini harus menggunakan perangkat komputer. Program ITEMAN dapat berjalan dengan baik di komputer dengan sistem operasi Windows 32 bit. Untuk Windows 64 bit diperlukan Program DOSBox untuk menjalankannya. Dengan demikian, untuk user yang menggunakan komputer dengan sistem operasi Windows 64 bit untuk menginstal program DOSBox terlebih dahulu. Dengan berbantuan komputer kegiatan analisis butir soal menjadi lebih mudah. Hal ini dikarenakan segala perhitungan dilakukan secara otomatis oleh komputer. 
Kondisi di lapangan menunjukkan bahwa sebagian besar guru belum melakukan kegiatan analisis butir terhadap soal yang mereka kembangkan (Prabowo dan Astuti, 2017: 7). Menurut mereka kegiatan analisis butir soal merupakan kegiatan yang rumit karena memerlukan waktu dan formula-formula untuk mengidentifikasi karakteristik butir. Untuk itu dengan dikembangkannya modul analisis butir menggunakan ITEMAN yang valid, efektif, dan praktis mampu menjawab permasalahan tersebut.

\section{Kesimpulan}

Penelitian ini telah berhasil mengembangkan modul analisis butir soal dengan menggunakan Item and Test Analysis (ITEMAN) yang valid, praktis, dan efisien yang dikembangkan melalui proses difine, design, develop, dan disseminate. Program ITEMAN bisa berjalan dengan mudah di komputer dengan sistem operasi Windows 32 bit. Untuk Windows 64 bit diperlukan Program DOSBox untuk menjalankannya. Dengan demikian, untuk user yang menggunakan komputer 64 bit untuk mengaktifkan program DOSBox.

\section{Pustaka}

Ary, D., Jacobs, L.C., dan Razavieh, A. (2010). Introduction to Research in
Education ( $8^{\text {th }}$ ed.). Belmont: Wadsworth, Cangage Learning.

Crocker, L. dan Algina, J. Introduction to Classical and Modern Test Theory. Toronto: Holt, Rine Hart, and Winston, Inc.

Instructional Assessment Resources (IAR). (2011). Item Analysis. Diakses pada 9 November 2013 dari University of Texas at Austin, Instructional Assessment Resources, IAR Web site: http://www.utexas.edu/academic/ctl /assessment/iar/students/report/item analysis.php

Jamlilah dan Purnawan, A. (2009). Pengembangan instrumen pengukuran hasil pembelajaran mata kuliah pronounciation. Diksi. 16(2): 122-133.

Kereh, C. T., Liliasari, Tjiang, P.C., dan Subandar, J. (2015). Validitas dan reliabilitas instrumen tes matematika dasar yang berkaitan dengan pendahuluan fisika inti. Jurnal Inovasi dan Pembelajaran Fisika. 2(1) : 36-46.

Lababa, Djunaidi. (2008). Analisis butir soal dengan teori tes klasik: sebuah pengantar. IQRA'. 5 : 29-37.

Otaya, Lian G. (2014). Analisis kualitas butir soal pilihan ganda menurut teori tes klasik dengan menggunakan program ITEMAN. Jurnal Manajemen Pendidikan Islam. 2 : 231-251.

Permendiknas Nomor 20 Tahun 2007 tentang Standar Penilaian.

Pisowacka, M.K. (2015). The use of the Iteman program in designing a general foreign language placement test. International Journal of Scientific and Research Publications. 5(12) : 537-541. 
Prabowo, A. dan Astuti, D. (2017).

Workshop dan Pendampingan

Penyusunan dan Analisis Instrumen

Hasil Belajar Peserta Didik

Berbasis Komputer. Yogyakarta: LPPM UAD.mm

Rosana, D. dan Setyawarno, D. (2016). Statistik Terapan untuk Penelitian Bidang Pendidikan. Yogyakarta: FMIPA UNY.

Suwarto. (2011). Teori tes klasik dan teori tes modern. Widyatama. 20(1) : 69-78.

Thiagarajan, S., Semmel, D. S., dan Semmel, M. I. (1974) Instructional Development for Training Teachers of Exceptional Children: A Sourcebook. Minnesota: ERIC. 